\title{
Sprawozdanie
}

\section{Seminarium Młodych Badaczy Prawa Konstytucyjnego nt.: Wtadza sądownicza w państwach europejskich, Waplewo, 5-7 kwietnia 2011 r.}

W dniach 5-7 kwietnia 2011 r. w Waplewie koło Olsztynka odbyło się trzecie już spotkanie naukowe z cyklu Seminariów Młodych Badaczy Prawa Konstytucyjnego. Ciężar zorganizowania seminarium przejął, jak zwykle, komitet organizacyjny, w skład którego wchodzą również pracownicy Katedry Prawa Konstytucyjnego Wydziału Prawa i Administracji Uniwersytetu Warmińsko-Mazurskiego w Olsztynie. Dzięki nim właśnie, na miejsce spotkania obrano Wojskowy Dom Wypoczynkowy, usytuowany na skarpie jeziora Maróz. Dystans od miejskiej cywilizacji oraz niezwykłe walory lecznicze okolicy pozwoliły w spokoju i rzeczowo podejść do problematyki, z jaką planowali zmierzyć się uczestnicy III Seminarium.

Otwarcia seminarium dokonała dr J. Juchniewicz (Uniwersytet Warmińsko-Mazurski), która serdecznie przywitała gości i wyraziła zadowolenie z tego, iż bez problemu udaje się utrzymać cykliczność spotkań. Nie brakuje bowiem ani chętnych do organizowania kolejnych seminariów, ani tym bardziej tematów wartych omówienia.

Pierwotnie Organizatorzy zaplanowali dwie sesje na 6. kwietnia i jedną na 7., jednak ze względu na dystans, jaki dzieli Waplewo od miejsc zamieszkania większości uczestników, zgłosili oni zamiar wyjazdu następnego dnia rano. Postanowiono więc, że wszystkie referaty omówione zostaną w jednym dniu.

Przewodniczenie sesji przedpołudniowej objął dr R. Grabowski (Uniwersytet Rzeszowski). Jako pierwszy wystąpił dr P. Czarny (Uniwersytet Jagielloński), który wygłosił referat pt. Sądownictwo konstytucyjne części składowych $w$ państwie federalnym. Sprawowanie sądownictwa konstytucyjnego przez części składowe federacji referent przedstawił głównie na przykładzie Stanów Zjednoczonych i Niemiec. Po zaprezentowaniu wybranych kwestii, 
dotyczących tytułowej problematyki, dr Czarny omówił, jakie są dobre i złe strony wprowadzenia takiego rozwiązania w państwach federalnych.

Dr M. Dąbrowski (Uniwersytet Warmińsko-Mazurski w Olsztynie) wystąpił z referatem Zasada kontradyktoryjności w postępowaniu przed Trybunałem Konstytucyjnym. Referent ten podważył zasadność twierdzenia, iż w postępowaniu przed Trybunałem Konstytucyjnym obowiązuje zasada kontradyktoryjności. Swoje stanowisko udowadniał przedstawiając podstawowe cechy zasady kontradyktoryjności w postępowaniu cywilnym oraz badając, czy i w jakim stopniu występują one w postępowaniu przed Trybunałem Konstytucyjnym. W trakcie swego wywodu dr Dąbrowski doszedł do wniosku, że postępowanie przed TK odpowiada raczej zasadzie śledczości.

W dyskusji, która miała miejsce po pierwszych dwóch referatach, uczestniczyli dr K. Urbaniak, dr P. Czarny i dr R. Balicki. Podnieśli oni, iż Trybunał tworzy swoisty kodeks postępowania konstytucyjnego, dobierając - w zależności od potrzeb - różne zasady z różnych procesów. Postępowanie takie stanowi jednak zbyt elastyczne podejście do procedury. Natomiast dr P. Mijal stwierdził, iż w czasie uchwalania ustawy o Trybunale oparto procedurę na K.p.c., ponieważ nie było jeszcze wówczas Prawa o postępowaniu przed sądami administracyjnymi, które jest postępowaniem dotyczącym legalności prawa.

Jako kolejny wystąpił dr K. Urbaniak (Uniwersytet A. Mickiewicza w Poznaniu), który w referacie Wybór sędziów sądów konstytucyjnych odniósł się do wielu kwestii szczegółowych, związanych z powoływaniem sędziów sądów konstytucyjnych, podkreślając częstokroć, które z ustaleń i mechanizmów stosowane są najczęściej. Wskazał przy tym na rozwiązania mające zagwarantować apolityczność sędziów. Na tym tle referent zaprezentował wybrane zagadnienia dotyczące rozwoju kontroli konstytucyjności prawa w Polsce po 1982 r. W trakcie swego wystąpienia dr K. Urbaniak poczynił też pewną prognozę dotyczącą przyszłego składu polskiego Trybunału Konstytucyjnego, a na wypadek jej spełnienia złożył osobistą deklarację.

Ostatnią osobą, która wystąpiła w pierwszej sesji, był dr J. Zaleśny (Uniwersytet Warszawski). W wystąpieniu pt. Dostęp ławników do informacji niejawnych przedstawił on problem, jaki zarysował się w minionych latach w zakresie potrzeby lub braku potrzeby przeprowadzania postępowania sprawdzającego wobec ławników, którzy mieli uzyskać dostęp do informacji niejawnych. Referent podkreślił, że co kilka lat Sąd Najwyższy zajmował 
w tej kwestii odmienne stanowisko. W związku z tym Rzecznik Praw Obywatelskich wystąpił do SN o przyjęcie jednolitego rozwiązania. Sąd uznał, że nie jest właściwa sytuacja, w której mamy dwa rodzaje ławników - tych z certyfikatem i tych bez, zatem każdy ławnik musi mieć dostęp do wszystkich materiałów dowodowych - również niejawnych.

Po tych dwóch referatach odbyła się dyskusja, w której uczestniczyli dr R. Balicki, dr P. Uziębło oraz dr P. Czarny. Odnosząc się do sposobu wyboru sędziów polskiego Trybunału Konstytucyjnego, dyskutanci podkreślili, że trudno byłoby obrać taką metodę wyboru sędziów, aby zagwarantować ich apolityczność. Ważne natomiast jest, aby procedury pozwalały wykluczyć powołanie kandydatów o skrajnych poglądach, aby wprowadzić procedurę zakwestionowania wyboru dokonanego przez Sejm oraz aby zwiększyć ilość etatów asystentów wspomagających w pracy sędziów TK.

Po zakończeniu bardzo ciekawej dyskusji prowadzący sesję zarządził przerwę obiadową. Po posiłku uczestnicy seminarium - chcąc skorzystać z niezwykłych walorów krajobrazowych i z pięknej wiosennej aury - udali się na spacer.

Drugiej sesji przewodniczyła dr J. Juchniewicz. Udzieliła ona głosu dr. P. Mijalowi (Uniwersytet Szczeciński), który wygłosił referat pt. Zagadnienie dopuszczalności kontroli konstytucyjności prawa Unii Europejskiej przez sądy krajowe. Doktor P. Mijal na wstępie zaznaczył, że właściwość do orzekania w kwestii kontroli konstytucyjności prawa przysługuje Trybunałowi Konstytucyjnemu, a sądy powszechne mają możliwość zwrócenia się w tej mierze do Trybunału z pytaniem prawnym. Wyraził on wątpliwość, czy któryś z trybunałów krajowych zdecyduje się na wystąpienie do ETS z pytaniem prejudycjalnym. Nie można się chyba spodziewać, że ETS kiedykolwiek orzeknie o niezgodności prawa europejskiego z krajowym. Ponadto mogłoby to być postrzegane jako przejaw nieporadności trybunału krajowego. W referacie poruszona została również kwestia bezpośredniego stosowania prawa wtórnego UE.

Po tym referacie rozpoczęła się ożywiona dyskusja, w której udział wzięli dr R. Balicki, dr K. Urbaniak, dr P. Czarny, dr P. Uziębło oraz dr M. Dąbrowski. Na wstępie podkreślone zostało, że na gruncie Konstytucji RP możemy mówić o pierwszeństwie stosowania prawa europejskiego, lecz nie o nadrzędności tego prawa nad krajowym. Dyskutanci spierali się o przydatność orzeczeń Solange w czasach, w których EWG należy już do 
historii. Doktor Czarny wyraził przekonanie, że w Unii byłby skuteczny jedynie zmasowany opór trybunałów konstytucyjnych przeciw prawu europejskiemu.

Następnie dr J. Juchniewicz zapowiedziała, że wystąpi dr T. Majerčák, (Uniwersytet P.J. Safarika w Koszycach) i podkreśliła, iż jest to pierwszy zagraniczny gość i jednocześnie referent w historii Seminariów Młodych Badaczy Prawa Konstytucyjnego.

W swoim wystąpieniu, odnoszącym się do Odpowiedzialności sędziów sądów powszechnych w Republice Słowackiej, referent przybliżył głównie kwestie odnoszące się do procedury pociągania do odpowiedzialności dyscyplinarnej sędziów. Następnie zwrócił uwagę, że konstrukcja systemu odpowiedzialności pozwala na uruchamianie postępowań w celu szykanowania sędziów. Umożliwia też powstawanie zjawiska kumoterstwa.

Dość oryginalną problematykę obrał sobie dr A. Ławniczak (Uniwersytet Wrocławski), który wygłosił referat Szczególne znaczenie losowania dla sądownictwa. Referent przybliżył zebranym źródła metody losowania. W XVIII w. wraz z rozwojem myśli o współcześnie rozumianej demokracji zakończyła się era losowania, aczkolwiek jeszcze wówczas brak było wyjaśnienia teoretycznego, udowadniającego wyższość głosowania. W odniesieniu do władzy sadowniczej - z Monteskiuszowskiego stwierdzenia, że sędzia jest ustami ustawy - wynika, że losowanie wykluczałoby niezależne orzekanie. W Polsce w K.p.k. dokonuje się losowania trzyosobowego składu sędziowskiego, co uniemożliwia ustalenie składu sędziowskiego i zwiększa szanse na bezstronność wyroku w razie równych kwalifikacji sędziów.

Ostatni referat Kontrola sąów nad partiami politycznymi wygłosiła mgr J. Uliasz (Uniwersytet Rzeszowski). Zwróciła ona uwagę, że władza sądownicza może kontrolować partie polityczne przy okazji wpisu do ewidencji (tu kontrola i nadzór Sądu Okręgowego w Warszawie oraz Trybunału Konstytucyjnego) i przy okazji kontroli sprawozdania finansowego i informacji, składanych przez partie. Referentka rozróżniła postępowania przed TK w zależności od tego, na jakim etapie dojdzie do przekazania Trybunałowi sprawy danej partii. Zwróciła ona też uwagę, że ustawa nie przewiduje stopniowalności sankcji, przez co w przypadku każdego stwierdzenia niezgodności Sąd Okręgowy powinien dokonać wykreślenia.

W doniesieniu do tego referatu odbyła się najbardziej chyba burzliwa dyskusja. Wzięli w niej udział dr T. Majerčák, dr P. Mijal, dr R. Balicki, dr 
A. Bień-Kacała, dr K. Urbaniak, dr P. Uziębło, dr M. M. Wiszowaty oraz dr M. Dąbrowski. Najszerzej dyskutowanym zagadnieniem był status partii politycznej przed wpisem. Podniesiono, że partia polityczna już na tym etapie może stanowić komitet wyborczy, który ma cel wyborczy i ma struktury (przykład początków Platformy Obywatelskiej). W związku z tym postawiono pytanie, czy można wnieść wniosek o delegalizację partii, która nie została wpisana jeszcze do ewidencji. W odniesieniu do tych zagadnień dyskutanci postawili więcej pytań niż odpowiedzi.

Tym sposobem uczestnicy seminarium uporali się z omówieniem wszystkich zagadnień, jakie zostały zaplanowane w ramach spotkania w Waplewie. Dyskusję nad częścią wątków z poszczególnych wystąpień kontynuowano jeszcze podczas wieczornego grilla. Wszak trudno wyczerpująco odnieść się do złożonych nieraz materii w dyskusji trwającej godzinę.

Na uwagę zasługuje zdyscyplinowanie zebranych i determinacja nakierowana na przygotowanie merytorycznie jak najlepszego wystąpienia. Uczestnicy seminarium przywykli już do tego, że przedstawione wyniki badań trzeba niejednokrotne obronić w toku rzeczowej, merytorycznej dyskusji.

Należy wyrazić więc zadowolenie, że Seminarium Młodych Badaczy Prawa Konstytucyjnego staje się stałym punktem w kalendarzu wydarzeń naukowych młodych konstytucjonalistów, a wygłoszone nań referaty nie giną w próżni. Artykuły będące pokłosiem tych spotkań mają szansę - po uzyskaniu pozytywnej recenzji wydawniczej - na opublikowanie w Przeglądzie Prawa Konstytucyjnego.

Anna Frankiewicz (Uniwersytet Opolski) 